\title{
Pengaruh Pola Asuh Orang Tua terhadap Kenakalan Remaja di Desa Tebuk Kecamatan Nita
}

\author{
Elisabeth Y. ${ }^{1}$, Yohanes Emanuel Besin ${ }^{2}$, M. Syahrun ${ }^{3}$ \\ ${ }_{1}^{1}$ Pogram Studi Pendidikan Ekonomi , IKIP Muhammadiyah Maumere \\ e-mail: yenijuliana@gmail.com \\ 2 Pogram Studi Pendidikan Ekonomi, IKIP Muhammadiyah Maumere \\ e-mail: besinemanuel@ymail.com \\ 3 Pogram Studi Pendidikan Ekonomi, IKIP Muhammadiyah Maumere \\ e-mail: torighgifari@gmail.com
}

\begin{abstract}
This study aimed to determine the effect of parenting parents on juvenile delinquency in Tebuk Village, Nita District. The method used in this study is a quantitative method, with the type of research used is the Ex-Post Facto research, with data analysis techniques namely the first Analysis Prerequisite Test consisting of the Normality Test, Linearity Test and Homogeneity Test, the second Descriptive Statistical Analysis and the third is the Statistical Analysis Test consisting of simple linear regression and t test (partial) with SPSS aided 22. The results of the study can be concluded that there is a positive influence between parenting parents and juvenile delinquency, which is indicated by the $t$ test results obtained by the $t$ value count 3.621 which is greater than $t$ table at the $5 \%$ significance level of 1.986 , then $t_{\text {count }}>t_{\text {table }}(3.621>1.986)$. If t arithmetic $>$ $T$ table then $\mathrm{HO}$ is rejected, so it can be concluded that there is a significant influence of Parenting Parents on Juvenile Delinquency
\end{abstract}

Keywords: Juvenile Delinquency, Parenting Parents

\begin{abstract}
Abstrak
Penelitian ini bertujuan untuk mengetahui pengaruh pola asuh orang tua terhadap kenakalan remaja di Desa Tebuk, Kecamatan Nita. Metode yang digunakan dalam penelitian ini adalah metode kuantitatif, dengan jenis penelitian yang digunakan adalah penelitian Ex-Post Facto, dengan teknik analisis data yakni yang pertama Uji Prasyaratan Analisis yang terdiri dari Uji Normalitas, Uji Linearitas dan Uji Homogenitas, yang kedua Analisis Statistik Deskriptif dan yang ketiga ialah Uji Analisis Statistik yang terdiri dari regresi linear sederhana dan Uji $t$ (parsial) dengan berbantuan SPSS 22. Hasil penelitian dapat disimpulkan bahwa terdapat pengaruh yang positif antara pola asuh orang tua dan kenakalan remaja, yang ditunjukkan dengan hasil uji t
\end{abstract}




\begin{abstract}
diperoleh nilai $\mathrm{t}$ hitung 3,621 yang lebih besar dari t tabel pada taraf signifikansi $5 \%$ sebesar 1,986 , maka $t_{\text {hitung }}>t_{\text {tabel }}(3,621>1,986)$. Apabila $t_{\text {hitung }}>t_{\text {tabel }}$ maka $\mathrm{H}_{0}$ ditolak, sehingga dapat disimpulkan bahwa terdapat pengaruh signifikan Pola Asuh Orang Tua terhadap Kenakalan Remaja.
\end{abstract}

Kata Kunci: Kenakalan Remaja, Pola Asuh

\title{
PENDAHULUAN
}

Akhir-akhir ini sering terjadi penyimpangan-penyimpangan sosial serta pelanggaran aturan yang ada di dalam masyarakat, seperti kenakalan remaja, melanggar tata tertib, melanggar nilai agama dan perbuatan kriminal. Tindakan remaja pada saat ini menunjukkan tanda-tanda bahwa kurang atau tidak adanya konformitas terhadap aturan sosial, penyimpangan sebagian besar terjadi pada remaja yang usianya di bawah 21 tahun. Pola asuh atau gaya pengasuhan dari orang tua sangat menentukan bagaimana remaja berperilaku dan bersikap dalam kehidupannya. Pola asuh orang tua dalam keluarga merupakan hal terpenting dalam pembentukan kepribadian anak.

Berikut ini dapat dikemukakan ciri-ciri pola asuh diantaranya yaitu pola asuh authoritarian (otoriter), pola asuh permisif dan pola asuh demokratis (Unayah \& Sabarisman, 2015). Sebagai orang tua sebaiknya mengetahui bagaimana memberikan sikap terhadap perubahan anaknya. Sebagian besar orang tua berusaha untuk memahaminya, namun justru membuat seorang remaja semakin nakal. Misalnya, dengan semakin mengekang kebebasan anak tanpa memberikannya hak untuk membela diri. Akibatnya, para orang tua mengeluhkan perilaku anak-anaknya yang tidak dapat diatur, bahkan terkadang membangkang mereka. Sehingga sering terjadi konflik keluarga, pemberontakan/perlawanan, putus asa dan resah pada diri remaja.

Papalia (2014) membedakan perilaku kenakalan ke dalam dua bagian yaitu; 1) Index offenses merupakan tindakan kejahatan baik yang dilakukan remaja maupun dewasa. Perbuatan-perbuatan itu meliputi perampokan, pencurian, pembunuhan, pemerkosaan. 2) Status offenses merupakan tindakan-tindakan yang 
tidak terlalu serius dan menentang status di usianya seperti membolos sekolah, lari dari rumah, mengonsumsi alkohol dan ketidakmampuan mengontrol diri sehingga menimbulkan perkelahian.

Kenakalan remaja adalah tindak perbuatan sebagian remaja yang bertentangan dengan hukum, agama dan norma-norma masyarakat, sehingga akibatnya dapat merugikan orang lain, mengganggu ketentraman dan juga merusak dirinya sendiri"(Sofyan, 2012).

Kenakalan remaja yang sering terjadi di Desa Tebuk adalah mabuk-mabukan, melakukan palak, ugal-ugalan dan judi. Menurut pernyataan kepala Dusun setempat, para remaja sering melakukan palak dan uang dari hasil palak tersebut digunakan untuk membeli minuman keras (arak), dari masalah tersebut dan dari hasil penelitian yang dilakukan dengan mengisi kuesioner yang dari masing masing indikator variabel mempunyai jumlah pernyataan yang berbeda dan melakukan wawancara, peneliti menemukan bahwa pola asuh yang digunakan oleh orang tua di Desa Tebuk adalah Pola Asuh Permisif dimana pola asuh ini memberikan pengawasan yang sangat longgar. Semua orang tua memberikan peluang pada anaknya untuk melakukan sesuatu tanpa pengawasan yang cukup dari orang tua sendiri. Orang tua lebih banyak tidak menegur bahkan memberi teguran apabila anak sedang dalam bahaya dan sangat sedikit bimbingan yang diberikan oleh orang tua.

Latar belakang tersebut membuat peneliti termotivasi untuk melakukan penelitian ini karena peneliti melihat di sekitar tempat penelitian banyak remaja yang berusia 10 tahun keatas melakukan palak, mengkonsumsi alkohol, berjudi bahkan ada beberapa remaja yang ugal-ugalan di jalan dan membuat masyarakat menjadi resah. Sehingga peneliti memilih judul ini untuk dijadikan bahan kajian dan referensi untuk peneliti lanjutan. Tujuan penelitian ini adalah untuk mengetahui pengaruh pola asuh orang tua terhadap kenakalan remaja di Desa Tebuk, Kecamatan Nita. 
Hasil dan pembahasan ini teori yang mendukung hasil penelitian ini adalah teori yang dikemukakan oleh Unayah (2015) yakni Mayoritas orang tua berusaha untuk mengerti dengan anaknya, namun justru kadang membuat remaja semakin nakal, misalnya dengan semakin membatasi kebebasan anak tanpa memberikan anak hak untuk membela diri. Dampaknya, para orang tua mengeluh akan perilaku anak-anaknya yang tidak bisa diatur, bahkan sering bertindak melawan mereka, sehingga kerap terjadi perselisihan yang terjadi dalam keluarga, disiden atau perlawanan, depresi, dan gelisah pada diri remaja

\section{METODE PENELITIAN}

Metode yang digunakan adalah metode kuantitatif. Pengambilan sampel menggunakan Probability Sampling yaitu teknik pengambilan sampel yang memberikan kesempatan yang sama bagi setiap unsur (anggota) populasi untuk dipilih menjadi anggota sampel (Sugiyono, 2018). Sampel dalam penelitian ini berjumlah 92 responden, jenis penelitian yang digunakan adalah penelitian ex-post facto. Menurut Sugiyono (2018) ex-post facto adalah sebuah penelitian yang dilakukan untuk menggali informasi tentang peristiwa yang telah terjadi dan kemudian selaras kebelakang untuk mengetahui faktor-faktor yang menyebabkan munculnya kejadian tersebut. Populasi yang dimaksud adalah remaja yang berjumlah 119 orang di Desa Tebuk, Kecamatan Nita.

Teknik pengumpulan data menggunakan kuesioner dan wawancara. Kuesioner diberikan kepada 92 remaja yang tersebar di IV Dusun di Desa Tebuk, Kecamatan Nita dan wawancara kepada beberapa orang tua dari 92 responden sebagai perwakilan. Angket disusun menggunakan skala Likert. Jawaban dari setiap item instrumen yang menggunakan Likert mempunyai tingkatan dari sangat positif sampai dengan negatif, yang digunakan untuk mengukur kedua variabel dalam penelitian ini yaitu variabel Pola Asuh dan variabel Kenakalan Remaja. Teknik analisi Semua penelitian ini menggunakan SPSS Statistic. 


\section{HASIL DAN PEMBAHASAN}

Dari pengujian angket pola asuh yang dilakukan diketahui bahwa $\mathrm{R}_{\text {hitung }}>$ $\mathrm{R}_{\text {tabel, }}$ sehingga dapat disimpulkan bahwa dari 34 pernyataan tentang variabel $\mathrm{X}$ (Pola Asuh) hanya 21 pernyataan yang dinyatakan valid, karena jumlah $\mathrm{R}_{h i t u n g}$ dari masing-masing pernyataan lebih besar dari pada $\mathrm{R}_{\text {tabel }}$ sedangkan 13 pernyataan tidak digunakan atau tidak valid dan dari pengujian angket Kenakalan Remaja yang dilakukan diketahui bahwa $\mathrm{R}_{h i t u n g}>\mathrm{R}_{\text {tabel, }}$, sehingga dapat disimpulkan bahwa dari 34 pernyataan tentang variabel Y (Kenakalan remaja) hanya 23 pernyataan yang dinyatakan valid, karena jumlah $\mathrm{R}_{h i t u n g}$ dari masing-masing pernyataan lebih besar dari pada Rtabel. sedangkan 11 pernyataan tidak digunakan atau tidak valid.

Pengujian reliabilitas menyatakan bahwa uji reliabilitas adalah sejauh mana hasil pengukuran dengan menggunakan objek yang sama akan memperoleh data yang sama. Uji reliabilitas dilakukan secara bersama-sama terhadap seluruh pernyataan (Sugiyono, 2018).

Tabel 1. Hasil Uji Reliabilitas Angket Pola Asuh (X) dan Kenakalan Remaja (Y)

\begin{tabular}{lccc}
\hline \multicolumn{1}{c}{ Variabel } & $\begin{array}{c}\text { Cronbach } \\
\text { Alpha }\end{array}$ & Jumlah Item & Interpretasi \\
\hline Pola Asuh Orang Tua (X) & 0,732 & 21 & Tinggi \\
\hline Kenakalan Remaja (Y) & 0,684 & 23 & Tinggi \\
\hline Jumlah & & 44 & - \\
\hline
\end{tabular}

Sumber: Data penelitian, diolah 2020 SPSS

Sesuai tabel di atas peneliti melakukan pengujian reliabilitas dan mendapatkan hasil dari masing-masing nilai Cronbach Alpha yaitu untuk variabel pola asuh sebesar 0,732 dan untuk variabel kenakalan remaja sebesar 0,684 > 0,5. Maka sesuai dengan ketentuan taraf signifikan $>\alpha$ data penelitian dapat dikatakan reliabel.

Analisis data menggunakan uji persyaratan analisis yaitu terdiri dari uji normalitas, linearitas dan Homogenitas. 
Tabel 2. Data Uji Prasyaratan Analisis

\begin{tabular}{cccc}
\hline Uji Persy. analisis & Dasar Keputusan & Signifikan & Keterangan \\
\hline Normalitas & $>0,05$ & 0,200 & Normal \\
\hline Linearitas & $<0,05$ & 0,001 & Linear \\
\hline Homogenitas & $>0,05$ & 0,302 & Homogen \\
\hline Sumber : Data diolah dengan SPSS,(2020) & &
\end{tabular}

Hasil dari uji normalitas yang dilakukan dengan menggunakan program SPSS Statistical 22, nilai signifikan Asymp. Sig (2-tailed) sebesar 0,200>0,05 maka sesuai dengan dasar pengambilan keputusan dalam uji normal Kolmogrov-Smirnov diatas dapat disimpulkan bahwa data tersebut berdistribusi normal. Hasil uji linearitas nilai signifikansi untuk variabel pola asuh terhadap kenakalan remaja yaitu $0,001<$ 0,05, maka dapat disimpulkan bahwa ada hubungan linear secara signifikan antara Pola Asuh terhadap Kenakalan Remaja atau asumsi linearitas terpenuhi dengan demikian pola asuh memiliki hubungan yang erat terhadap kenakalan remaja. Hasil Uji menggunakan software SPSS versi 22.0, hasil uji homogenitas nilai signifikansi adalah 0,302. Karena nilai sig. 0,302 >0,05, maka dapat disimpulkan bahwa varian data kenakalan remaja di Desa Tebuk, Kecamatan Nita adalah Homogen.

Hasil analisis uji t diperoleh hasil bahwa variabel pola asuh orang tua berpengaruh signifikan terhadap variabel kenakalan remaja di Desa Tebuk, Kecamatan Nita. Hal tersebut ditunjukkan dari hasil analisis korelasi product moment sebesar 3,621 , jadi thitung $>$ tabel $(3,621>1,986)$. Koefisien determinasi sebesar 0,127 atau $12,7 \%$ setelah melalui proses perhitungan koefisien determinan $\left(\mathrm{r}^{2}\right)$ maka berpengaruh positif, artinya dengan adanya pola asuh yang menyimpang, maka remaja dengan segala tingkah lakunya melakukan hal-hal yang dilarang atau hal-hal yang harusnya tidak boleh dilakukan. Sedangkan 87,3\% merupakan faktor yang mempengaruhi variabel kenakalan remaja dari faktor lain yang tidak diteliti oleh peneliti.

Selain itu juga diperoleh persamaan regresi kenakalan $Y=56,305+0,199 x$ Pola Asuh. Persamaan tersebut sesuai dengan rumus regresi linier sederhana yaitu 
$\mathrm{Y}=\mathrm{a}+\mathrm{bX}$, dimana $\mathrm{Y}$ merupakan lambang dari variabel terikat, $\mathrm{a}$ atau konstanta dan $b$ adalah koefisien regresi untuk variabel bebas. sehingga dapat disimpulkan dari hasil uji t, Sehingga dapat disimpulkan bahwa terdapat pengaruh pola asuh orang tua terhadap kenakalan remaja di Desa Tebuk Kecamatan Nita. Hal ini didukung dengan penelitian terdahulu yang dilakukan oleh (Savitri Suryandari, 2016) menyatakan bahwa terdapat Pengaruh Pola Asuh Orang Tua terhadap Kenakalan Remaja di Komplek Departemen Kesehatan Ciputat, Hal ini juga didukung dengan penelitian terdahulu yang dilakukan oleh (Purwaningtyas, 2019) hasil penelitian menyatakan bahwa terdapat pengaruh Pengasuhan Permissive Orang Tua dan Kenakalan Remaja di SMU Surabaya.

\section{KESIMPULAN}

Berdasarkan hasil penelitian yang dilakukan, peneliti mengalami beberapa kesulitaan yakni ada beberapa remaja yang tidak mau mengisi kuesioner dan adapula orang tua yang tidak mau diwawancarai karena alasan tertentu, ada orang tua yang tidak mau memberikan jawaban karena takut terhadap anaknya yang sering membuat keributan di rumah.

Hasil penelitian diperoleh bahwa terdapat pengaruh yang signifikan antara pola asuh orang tua dan kenakalan remaja yang ditunjukkan dengan hasil uji $\mathrm{t}$ diperoleh nilai thitung 3,621 yang lebih besar dari tabel pada taraf signifikansi 5\% sebesar 1,986, maka $t_{\text {hitung }}>t_{\text {tabel }}(3,621>1,986)$.

Berdasarkan analisis koefisien determinasi didapatkan hasil sebesar 12,7\% sehingga pola asuh orang tua berpengaruh $12,7 \%$ terhadap kenakalan remaja di Desa Tebuk, Kecamatan Nita. Sedangkan 87,3\% merupakan faktor yang mempengaruhi variabel kenakalan remaja dari faktor lain yang tidak diteliti oleh peneliti, sehingga peneliti selanjutnya dapat meneliti faktor lain selain pola asuh orang tua yang dapat mempengaruhi kenakalan remaja. Saran untuk peneliti selanjutnya agar dapat mengembangkan penelitian ini dan juga dapat meneliti 
variabel lain yang mempengaruhi kenakalan remaja atau dengan menggunakan metode lain, sehingga informasi yang diperoleh dapat lebih bervariasi dari angket yang jawabannya telah tersedia.

\section{DAFTAR RUJUKAN}

Casmini. (2007). Emotional Parenting. Yogyakarta:Pilar Media.

Kartono, Kartini. (2002). :Patologi Sosial 2 Kenakalan Remaja. Jakarta: PT Raja Grafindo Persada.

Kartono, Kartini. (2006). Peran Keluarga Memandu Anak. Jakarta : CV. Rajawali. Papalia, D.E., Martorell, G. (2014). No Title. In Experience Human Development (13thed.). New York: NY: McGraw-Hill.

Purwaningtyas, F. D. (2019). Pengasuhan Permissive Orang Tua dan Kenakalan pada Remaja. Jurnal Penelitian Psikologi, 10(2), 12.

Savitri Suryandari. (2016). Jurnal Inovasi Pendidikan Dasar. Jurnal Inovasi Pendidikan Dasar, 4(1), 23-29. Retrieved from https://www.researchgate.net/profile/Rully_Prahmana/publication/304022 469_PENINGKATAN_KEMAMPUAN_PENALARAN_MATEMATIS_SISWA_MENG GUNAKAN_PENDEKATAN_PENDIDIKAN_MATEMATIKA_REALISTIK/links/57 63a4e508ae192f513e458e.pdf

Sofyan, W. (2012). Remaja dan Masalahnya. Bandung: Alfabeta.

Sugiyono. (2018). Metode Penelitian kuantitatif, Kualitatif dan R\&D. Bandung: Alfabeta.

Unayah, N., \& Sabarisman, M. (2015). the Phenomenon of Juvenile Delinquency and Criminality. Sosio Informa, 1(2), 121-140. Retrieved from https://media.neliti.com/media/publications/52810-ID-fenomenakenakalan-remaja-dan-kriminalit.pdf 